\title{
ANDRZEJ GRZELAK \\ »To czyńcie na moją pamiątkę«. Z dziejów liturgii Mszy świętej sprawowanej w Kościele zachodnim
}

\section{Sprawowanie Pamiątki Pana w Kościele pierwotnym (do IV w.)}

Z przebitego boku Chrystusa Ukrzyżowanego zrodzil się Kościól i, poczawszy od dnia Zmartwychwstania, nieustannie wzrasta w liczbie swoich czlonków. Czlowiek, który przyjal orędzie Ewangelii i uwierzył w Chrystusa Zbawiciela, przez sakrament chrztu, staje się czlonkiem Kościoła. Ta przynależność do Kościoła uzdalnia i zobowiązuje chrześcijanina do regularnego udziału w Eucharystii. Chrzest i Eucharystia są obecne od samego początku istnienia Kościola i od samego początku w życiu każdego chrześcijanina. Sakramenty te, zapowiadane przez Jezusa w czasie Jego publicznej dzialalności, i urzeczywistniane przez Niego po Zmartwychwstaniu, moca Ducha Świętego, rodzq Kościól czyli święte zgromadzenie i nieustannie wlączaja chrześcijan w misję mesjańską Chrystusa, odnoszącą się do Boga i świata. Tak jak niemożliwe jest powstanie i istnienie Kościola $\mathrm{i}$ życia $\mathrm{z}$ wiary poszczególnych chrześcijan bez Jezusa Chrystusa, tak też niemożliwe jest jego istnienie bez chrztu i Eucharystii.

Od samego dnia Zmartwychwstania Apostolowie i pierwsi wyznawcy regularnie schodzq się razem, aby wypelniać polecenie Zbawiciela wypowiedziane w Wieczerniku podczas Ostatniej Wieczerzy: To czyńcie na moja pamiqtkę (por. Łk 22,19 ). To polecenie oznacza zobowiazzanie do sprawowania Eucharystii. Wypelnianie tego zobowiązania zostało znamiennie "doprecyzowane" przez fakt przyjścia Zbawiciela do Apostolów w dniu Zmartwychwstania (Lk 24, 36; J 20, 19) i ponownie osiem dni później, czyli również pierwszego dnia tygodnia (J 20, 26). Stąd też wyznawcy Chrystusa regularnie gromadzą się wszyscy razem w tym wlaśnie dniu, aby sprawować Pamiątkę Pana czyli Eucharystię. 
Zmartwychwstaly Chrystus w ciagu czterdziestu dni przychodzi do swoich, aby nie tylko ukazać tajemnice „zwycięstwa" nad swoją śmiercią, ale aby przede wszystkim „ukazać” znaczenie ściśle ze sobą związanych tajemnic chrztu, Eucharystii i Kościola.

Podobnie jak dla Żydów szabat byl dniem świętym, tak również Zmartwychwstaly Pan „ukazuje” nowy święty czas, którym stal się pierwszy dzień po szabacie (nazwany później niedziela). Zatem niedziela przypomina nie tylko historyczny dzień Zmartwychwstania Chrystusa i dzień Zeslania przez Niego Ducha Świętego, ale także ukazuje się jako nowy dzień święty. Dzień, którego czas należy się Bogu. Zmartwychwstaly Pan (Kyrios) objawia, że niedziela ma być dniem spotkania Jego wyznawców z Nim, ma być dniem wspólnoty uczniów z Panem czyli dniem Kościoła, który sprawuje Jego Pamiqtkę to znaczy Eucharystię. Sprawowanie tego obrzędu stanowi istotę i punkt kulminacyjny „świętowania" niedzieli.

\section{Liturgia sprawowana w Kościele czasów apostolskich}

Pierwotny przebieg niedzielnej liturgii można odtworzyć, uważnie analizując wzmianki o Eucharystii zawarte w księgach Nowego Testamentu. W księgach tych spotykamy cztery takie teksty: w pierwszym Liście św. Pawła do Koryntian (11, 20-23. 23-26), w Ewangelii wedlug św. Lukasza $(22,14.20)$ w Ewangelii wedlug św. Marka $(14,22-25)$ i Ewangelii wedlug św. Mateusza $(26,26-30)$.

Najstarszą relację o ustanowieniu Eucharystii znajdujemy w pierwszym Liście św. Pawla do Koryntian napisanym ok. roku 55. Święty Pawel nawiązuje w nim do faktu regularnych, niedzielnych zgromadzeń wyznawców nowej wiary, jakie odbywaly się w Koryncie. W czasie tych spotkań opowiadano wydarzenia z życia Pana Jezusa, odprawiano obrzęd, który Jezus polecil wypelniać uczniom na swoja pamiatkę i brano udział w braterskiej uczcie. W kontekście tych zgromadzeń św. Pawel przypomina Koryntianom, że Eucharystia jest darem Pana i bierze swój początek od nocy, w której On spożyl Ostatnią Wieczerzę z Apostolami, a następnie dobrowolnie wydał się w ręce oprawców.

Sposób i forma jakimi posłużył się św. Paweł pisząc o Pamiq̨ce Pana świadcza, że prawda o Eucharystii i sam obrzęd jej sprawowania byly adresatom listu dobrze znane. Obrzęd zaś byl sprawowany wedlug utrwalonego już schematu zakorzenionego w wydarzeniach Ostatniej Wieczerzy ${ }^{1}$. Podobny opis ustano-

\footnotetext{
${ }^{1}$ R. C a bi e: L'Eucharistie, w: L'Eglise en Prerie. Red. A. G. Martimort: Paris 1983 s. $21-22$.
} 
wienia Eucharystii w swojej Ewangelii zawiera także św. Lukasz podkreślając jej przebieg $^{2}$.

I opis Pawla i opis Lukasza wyraźnie odnoszą się do sprawowanego wśród gmin chrześcijańskich obrzędu liturgicznego nazywanego Pamiątkq Pana. Znamienne jest podkreślanie jego przebiegu. Nawiąuje on jednoznacznie do tego, co stało się w Wieczerniku, ale także i do tradycyjnej, świątecznej uczty żydowskiej, która składała się z następujących elementów:

a) przygotowanie wina (pierwszy kielich), któremu towarzyszyła bardzo stara modlitwa: Błogoslawiony jesteś Boże, który nam daleś wino, owoc winnego krzewu;

b) sama uczta rozpoczyna się obrzędem lamania chleba przez ojca rodziny, który przekazywal go wszystkim biesiadnikom;

c) ucztę kończył ostatni kielich, nad którym odmawiano najdluższą i najważniejszą modlitwę dziękczynną (Modlitwa 18-stu Błogosławieństw).

$Z$ calą pewnością możemy stwierdzić, że w czasie Ostatniej Wieczerzy Pan Jezus wypowiedzial slowa konsekracji nad chlebem w czasie jego lamania (czyli na poczatku wieczerzy), oraz slowa konsekracji nad winem podczas ostatniego kielicha czyli po wieczerzy.

Obok tekstów o Eucharystii Pawla i Lukasza, w Nowym Testamencie spotykamy także wzmianki o niej w Ewangeliach Marka i Mateusza. Jednak - szczególnie gdy chodzi o przebieg sprawowanego obrzędu Eucharystii - to ci dwaj ostatni ukazują inną tradycję niż ta, która była udziałem Koryntian. Mianowicie nie wspomina się ani w jednej, ani w drugiej Ewangelii o pierwszym kielichu, sama zaś konsekracja chleba i wina nie są od siebie oddzielone i mają miejsce $w$ czasie wieczerzy, a nie po wieczerzy. Trzecim nowym elementem tych „wzmianek" jest rozbudowanie formuly konsekracyjnej nad winem.

Co było przyczyną tych różnic a ściślej ujmując, tych świadomych zmian? Być może należy je thumaczyć ewolucją praktyki liturgicznej, która w ten sposób pragnęla uczestnikom bardziej przybliżyć (ukazać) treść uobecnianego Daru Bożego. Oprócz tego, zmiany te świadczą również o bardzo wczesnym odlączeniu sprawowania Eucharystii od zwyczajnego posilku. Ten posilek, który przez dość dlugi czas w Kościele pierwotnym byl zwiazany ze sprawowaniem Eucharystii, bardzo wcześnie zaczyna być traktowany jako ważna, ale zupełnie inna część zgromadzenia. W pierwszych latach istnienia Kościoła spożywano go „przed" lub „po" celebracji Pamiątki Pana, a później - pod koniec I w. - tylko po Lamaniu Chleba.

\footnotetext{
${ }^{2}$ Por. W. R o r d o r f: La celebration dominicale de la sainte cene dans L'Eglise Ancienne. W: Liturgie, Foi et Vie des premiers chretiennes. Paris 1986 s. 59-71.
} 
Zatem jeszcze w czasach apostolskich mamy do czynienia $\mathrm{z}$ dwiema odmiennymi tradycjami, dotyczacymi sposobu sprawowania Eucharystii. Jednak mimo różnic, te dwie tradycje posiadają tę samą podstawową strukturę:

1. Jezus wzią chleb, następnie kielich $\mathrm{z}$ winem.

2. Składał dziękczynienie (blogoslawil).

3. Lamal chleb.

4. Dawal swoim uczniom.

Do gestu „dawania” zostaly dolaczone slowa Jezusa: To jest moje Ciało za was wydane. To jest kielich Krwi mojej nowego i wiecznego Przymierza. Slowa te zostaly wypowiedziane nad chlebem i winem w czasie Ostatniej Wieczerzy, w kontekście szczególnego zgromadzenia tworzonego przez Chrystusa i Jego uczniów oraz Jego dziękczynnej modlitwy zanoszonej do Ojca ${ }^{3}$.

Schemat tej kompozycji, dotyczący Eucharystii utworzonej przez „,slowaklucze" zdaje się wskazywać, że mamy tutaj do czynienia nie z tekstem utworzonym przez Łukasza czy Pawla badź też Marka czy Mateusza, lecz z tekstem przejętym, zacytowanym i niewatpliwie już używanym w niedzielnej Liturgii sprawowanej przez wyznawców nowej wiary ${ }^{4}$. Owe cztery „slowa-klucze” określily uklad (porządek - ordo) drugiej części Mszy św.:

1. Przygotowanie darów - czyli branie darów, aby je zlożyć na ołtarzu.

2. Modlitwa eucharystyczna, w czasie której jednym z jej elementów jest opowiadanie o Ustanowieniu.

3. Eamanie konsekrowanego Chleba.

4. Komunia święta.

Niektóre z tych „slów-kluczy” daly nazwę calemu obrzędowi: na przyklad powszechnie określa się Mszę św. jako „Eucharystię” - nazwa ta wywodzi się od charakteru modlitwy, która towarzyszy mszalnym czynnościom (skladać dziękczynienie - eucharistein). Podobnie lamanie Chleba, które od samego początku, ma miejsce w czasie każdej Eucharystii, stało się wyrażeniem określającym calą Mszę świętą.

Pierwotne gminy chrześcijańskie, które z tak wielkim zapalem sprawowaly święte czynności przekazane im przez Apostolów, nie posiadaly jakiegoś szczególnego wyrażenia (terminus technicus) na określenie shużby Bożej. Nie mniej jednak warto zauważyć, że na określenie tych ściśle chrześcijańskich celebracji, których sercem bylo sprawowanie Pamiq̨tki Pana, pojawia się też termin leitourgia (Dz 13, 2; Hbr 8, 6; 12, 28).

\footnotetext{
${ }^{3} \mathrm{C}$ a bi e, dz. cyt., s. 23.

${ }^{4}$ Por. T. J. T a $11 \mathrm{e} \mathrm{j:} \mathrm{Les} \mathrm{origines} \mathrm{de} \mathrm{l'anne} \mathrm{liturgique,} \mathrm{Paris} 1990$ s. 14-18.
} 
Zaś na przelomie I i II w. spotykamy także pojęcie thysia, które akcentuje ofiarniczy charakter czynu Chrystusa, szczególnie Jego Męki, Śmierci i Zmartwychwstania. Treść tego terminu zostala jeszcze bardziej zaakcentowana w wyrażeniu thysiasterion - oltarz, czyli miejsce, na którym składa się zbawczą ofiarę Chrystusa (Hbr 13, 10). Termin thysia (ofiara) pozwala doprecyzować termin „liturgia" i rozumieć go jako czyn Chrystusa, który swoimi zbawczymi owocami obejmuje wielu to znaczy wierzqcych. Dla Klemensa Rzymskiego leiturgia jest slużbą Boga dla wspólnoty i służbą wspólnoty wobec Boga ${ }^{5}$.

\section{Czas (dzień) sprawowania Eucharystii}

Chrześcijanie schodzili się razem, aby sprawować Pamiatkę Pana. Czynili to na wyraźne polecenie Jezusa wypowiedziane w Wieczerniku i potwierdzone po Zmartwychwstaniu. W dniu Zmartwychwstania, w pierwszym dniu po szabacie Chrystus Pan (Kyrios) przychodzi do wieczernika, do Apostołów, aby być z nimi. Ponownie czyni to samo osiem dni później czyli także pierwszego dnia po szabacie to znaczy pierwszego dnia tygodnia. Zatem „pierwszy dzień tygodnia” staje się nie tylko dniem, w którym Jezus zmartwychwstal, ale jest on równocześnie dniem, w którym Uwielbiony Pan pragnie spotykać się ze swoimi. W tym właśnie dniu i w czasie tego spotkania objawia im prawdę o swoim zwycięstwie nad śmiercią i prawdę o dokonanym przez siebie odkupieniu i zbawieniu a poprzez dar Ducha Świętego - daje im udzial w tych tajemnicach. Apostołowie, napetnieni Duchem Świętym zostali, w nieznany dotąd sposób, zjednoczeni ze Zmartwychwstalym Panem i między sobą oraz uzdolnieni do przekazywania tej nowej rzeczywistości innym.

Apostolowie stanęli w obliczu dwóch prawd: dzień Zmartwychwstania Chrystusa staje się nowym dniem świętym, w którym Uwielbiony Chrystus pragnie w sposób szczególny być ze swoimi. Druga prawda jest ta, że dostęp do tej Obecności Pana dokonuje się nie tylko poprzez cudowne zjawienia Zmartwychwstalego (chrystofanie), ale poprzez sprawowanie Eucharystii, która Pan przekazal Apostołom w czasie Ostatniej Wieczerzy w Wieczerniku na progu swojej godziny. Stąd też od samego początku dzień Zmartwychwstania, czyli pierwszy dzień po szabacie stał się dniem zgromadzenia wszystkich wyznawców Chrystusa, aby doświadczyć tajemnicy Jego obecności, Jego modlitwy, ofiary i komunii z Nim, co się dokonywalo poprzez Eucharystię, której zawsze przewodniczyl apostol lub jego następca.

Tak więc „pierwszy dzień tygodnia” stal się dniem, w którym na wyraźne polecenie Zmartwychwstalego Pana sprawowano Eucharystię i w taki sposób, jak to określił Pan Jezus podczas Ostatniej Wieczerzy. Pierwsi wyznawcy Chrystusa byli świadomi także i tego, że sprawujac Eucharystię uobecniaja całe dzielo

\footnotetext{
${ }^{5}$ 1, 44, 3; Por. Didache 15, 10.
} 
Chrystusa, w którym spełnily się wszystkie mesjańskie obietnice, zapowiadane w księgach Starego Testamentu. Ich zaś ostatecznym wypehnieniem byla Śmierć i Zmartwychwstanie Chrystusa, na co jednoznacznie i mocno wskazują wystapienie św. Piotra w dniu Pięćdziesiatnicy (Dz 2, 14-36) i wszystkie wydarzenia opisane w Dziejach Apostolskich. Świadkami tej samej prawdy są także wszyscy pozostali Apostolowie ze św. Pawłem na czele (Dz 20,7-11).

\section{Miejsce sprawowania Eucharystii}

Pierwsi wyznawcy Chrystusa wiedzieli, że Jego ofiara krzyżowa zastapiła wszystkie ofiary Starego Prawa. Te zaś byly przez wieki skladane w światyni w Jerozolimie, na wzgórzu syjońskim, w miejscu wybranym przez Boga. Warto postawić pytanie o miejsce sprawowania Eucharystii? Czy byla nim jakaś nowa Swiqtynia?

Chrześcijanie od samego początku byli świadomi i tego, że prawdziwa, a także jedyną świątynią, czyli miejscem spotkania z Bogiem i skladania Mu doskonalych ofiar jest sam Chrystus Zmartwychwstaly. Ich świadomość obejmowala również to, że oni sami przez chrzest, jaki otrzymali od Chrystusa, stali się także światyniq Boga, to znaczy zostali uzdolnieni do skladania doskonałej ofiary Bogu razem z Chrystusem, przez Niego i w Nim. Samo zaś sprawowanie Eucharystii przeżywali nie tylko jako tajemnicę uobecnienia ofiary Chrystusa, ale także jako jej składanie razem z Nim. Zatem wlaściwym miejscem jest to, gdzie jest Chrystus i gdzie gromadzi się wspólnota Jego wyznawców.

Początkowo Eucharystię sprawowano po domach (Dz 2, 46), czyli w prywatnych mieszkaniach poszczególnych członków danej wspólnoty. Chrześcijanie, szczególnie wywodzacy się z narodu wybranego, mieli świadomość świętości miejsca, w którym sklada się ofiary przyjęte przez Boga. W świątyni jerozolimskiej do miejsca skladania ofiar mieli prawo wstępu tylko kaplani skladajacy ofiarę. Zaś do miejsca najświętszego (Święte świętych) mógl wejść tylko raz w roku arcykapłan, któremu przypadł los złożenia ofiary kadzenia. Miejsce skladania ofiar staje się miejscem szczególnym, świętym to znaczy miejscem szczególnej obecności Boga, obecności, która staje się „dostępna” dla wierzacych. Wobec tego miejsce obecności staje się przede wszystkim miejscem wylączonym ze zwyczajnego użytku świeckiego. Czy tak było w przypadku sprawowania Eucharystii? W I w. spotykamy wzmiankę o stole, przy którym sprawowano Eucharystię, określająca go jako stól ofiarny i przez to jako szczególne miejsce święte. Miejsce, przy którym nie można już spożywać zwyczajnego posilku a nawet związanej z Eucharystia braterskiej agapy. Stól, przy którym sprawowano $P a-$ miatkę Pana staje się miejscem wyłączonym, przeznaczonym tylko dla tej celebracji. Odkrycia archeologiczne z Doura Europos (ok. 215 r.) każą sądzić, że 
bardzo wcześnie miejsca celebracji Eucharystii (szczególnie stól-ołtarz) byly odpowiednio przygotowane do sprawowanej liturgii i wlaściwie przyozdobione.

\section{Początki Liturgii Slowa}

Skoro sprawowanie Eucharystii jest uobecnianiem Osoby i dziela Chrystusa-Mesjasza, to nic dziwnego, że te święte czynności byly poprzedzone świadectwami o życiu Mesjasza i spelnionej przez Niego misji. Najpierw byly to bezpośrednie, żywe świadectwa Apostolów „naocznych świadków” ziemskiego życia Jezusa oraz świadectwa Pisma Świętego Starego Przymierza zawierajacego mesjańskie proroctwa. Z biegiem lat, w ciągu I w. świadectwa apostolów przyjęly utrwalony ksztalt Ewangelii, Dziejów Apostolskich, Listów i Apokalipsy, i także one, podobnie jak Księgi Starego Testamentu, byly odczytywane w czasie eucharystycznych zgromadzeń. Początkowo byla to tak zwana lektura ciagla (lectio continua - czytano księgę po księdze. W polowie II w. św. Justyn napisał, że czytano tak dlugo, jak czas na to pozwalat ${ }^{6}$ ).

Tak więc sam obrzęd eucharystyczny poprzedzalo czytanie Pisma św., zarówno ze Starego jak i Nowego Testamentu. Lekturze towarzyszylo śpiewanie psalmów i hymnów zakończonych nauczaniem tego, który przewodzil liturgii. Shuchanie i rozważanie tekstów biblijnych niewaṭpliwie pierwszym wspólnotom chrześcijańskim przypominało liturgię żydowską odprawianą w każdy szabat $\mathrm{w}$ synagogach, kiedy to czytano Prawo i Proroków, gloszono homilię i śpiewano psalmy, lecz we wspólnotach chrześcijańskich liturgia ta miala zupelnie inne, nowe znaczenie. O ile w synagogach liturgia Slowa przypominała wielkie dzieła Boga dokonane w przeszłości narodu wybranego, to tutaj także, przypominając mesjańskie obietnice wypełnione w Chrystusie, przede wszystkim przygotowywala do rozpoznania tych obietnic, uobecnianych poprzez mające bezpośrednio po niej nastapić czynności liturgiczne oraz do ich przyjęcia przez wiarę. Księgi Nowego Testamentu świadczą o spełnieniu się w ziemskim życiu Jezusa z Nazaretu wszystkich mesjańskich obietnic zawartych w Księgach Starego Prawa, stąd też te nowe Pisma zaczęly cieszyć się tym samym autorytetem co Księgi Starego Przymierza.

\section{Liturgia $\mathrm{z}$,improwizowanymi” modlitwami}

W czasach apostolskich chrześcijanie nie posiadali wielu z pośród tych rzeczy, bez których my nie potrafimy sobie dzisiaj wyobrazić życia Kościola i sprawowania jego liturgii, nie posiadali wlasnych miejsc kultu (kościolów), nie posiadali szat liturgicznych, nie posiadali ksiag itp., a jednak doświadczali calego bogactwa życia liturgicznego.

\footnotetext{
${ }^{6}$ I Apologia 67.
} 
Pierwszą i najważniejszą Księgą liturgiczna, a przez pierwsze trzy wieki chrześcijaństwa prawie jedyną - byla Księga Pisma Świętego. Chociaż w tym okresie nie było jeszcze ksiag liturgicznych, to liturgia chrześcijańska od samego poczatku swego istnienia miala ściśle określony porządek, zarówno jeżeli chodzi o glówne elementy danych celebracji liturgicznych (schemat sprawowania liturgii) jak i gdy chodzi o treść wypowiadanych przez celebransa (przewodniczącego) modlitw. Modlitwy te, co prawda byly improwizowane i każdy z celebransów zanosil modlitwy do Boga w imieniu wspólnoty, której przewodzil, ile tylko mógl (jak się wyrazil św. Justyn, autor z II w. w swojej Apologii), to jednak ich treść byla zdeterminowana (określona) przez uobecniająca się rzeczywistość sprawowanego misterium. Improwizacja zatem nie oznacza tutaj dowolności, a wręcz przeciwnie, naklada na celebransów zobowiązanie, aby w duchu uwielbienia, w wierności tradycji apostolskiej i w granicach wolności, ukazywali święte tajemnice, posługując się przede wszystkim sformułowaniami Pisma Świętego.

Spośród tych modlitw wypowiadanych w czasie sprawowania chrztu, Eucharystii, obrzędu święceń, blogosławieństw, szczególne znaczenie posiadają Modlitwy eucharystyczne nazywane anaforami ${ }^{7}$.

\section{Konieczność posługiwania się modlitwami zatwierdzonymi przez synody lub sobory}

Modlitwa dziękczynna jest nieodłaczną częścią liturgii eucharystycznej od samego poczatku. Jej źródła znajduja się w żydowskiej Modlitwie Osiemnastu Błogosławieństw i Arcykapłańskiej Modlitwie Chrystusa. Na formę i treść najstarszych Modlitw eucharystycznych (anafor) ważny wplyw mialy dwa czynniki: pierwszym bylo bardzo mocne pragnienie zachowania we wszystkim tradycji apostolskiej, drugim zaś troska o to, aby ich treść i forma odpowiadaly przekazanej przez Apostolów wierze Kościola dotyczącej Eucharystii. Mialo to ważne znaczenie także wobec zagrożenia, jakie stanowily ówczesne herezje.

Pragnienie wspólnot chrześcijańskich, aby jak najgodniej sprawować $P a$ miqtke Pana spowodowało, że one, podobnie jak w czasach apostolskich przyjmowaly Pisma apostolskie od poszczególnych wspólnot, tak w późniejszym okresie przekazywano sobie również teksty anafor, których autorstwo często bylo przypisywane Apostolom lub uczniom apostolskim.

Modlitwy używane w sprawowaniu liturgii powinny najlepiej jak tylko to jest możliwe, wyrażać treść sprawowanych tajemnic. Ten wymóg stał się powodem, że synody i później sobory, zaczęly się domagać, aby w czasie sprawowania Liturgii używano tylko modlitw zatwierdzonych bądź na synodzie czy sobo-

${ }^{7} \mathrm{Cabi}$ e, dz. cyt., s. 35-50; por. B. Nado $1 \mathrm{sk}$ i: Liturgika. T. IV. Eucharystia. Poznań 1992 s. $18-20$ 
rze lub przynajmniej przez okolicznych biskupów. Taki kanon po raz pierwszy zostal przyjęty w 393 r. przez Synod w Hipponie w Afryce Pólnocnej.

\section{Początki ksiąg liturgicznych}

\section{Rzymskie sakramentarze - Leona Wielkiego, Gelazego i Grzegorza Wielkiego}

Zatwierdzane na synodach i soborach teksty Modlitw eucharystycznych (anafor) $\mathrm{i}$ innych modlitw używanych w liturgii a odmawianych przez biskupa lub prezbitera daly poczatek najstarszym zbiorom modlitw przeznaczonych do sprawowania Eucharystii $\mathrm{w}$ dana niedziele $\mathrm{w}$ ciagu roku liturgicznego. Taki „niedzielny" zestaw modlitw shużących do sprawowania poszczególnych Mszy św. nazywano formularzem. Osobne rękopisy takich formularzy w Rzymie określano terminem libelli (książeczki). Z kolei zbiór formularzy calego roku kościelnego w Kościele zachodnim nazywano sakramentarzem, a w Kościele wschodnim - euchologion. Spośród najstarszych sakramentarzy trzeba wymienić trzy: sakramentarz leoniański, gelazjański i gregoriański ${ }^{8}$.

Sakramentarz leoniański pochodzi z V w. i stanowi zbiór modlitw używanych w liturgii przez papieża Leona Wielkiego (440-461). Znajduja się w nim formularze mszalne na niektóre dni roku liturgicznego. Sakramentarz ten stanowi prosty zbiór libelli. Powstal on dzięki staraniom biskupa Werony, który pragnąl w swoim Kościele pozostać wiernym liturgii papieskiej i w ten sposób uchronić się przed wplywem herezji ariańskiej. Kodeks ten do dzisiaj przechowywany jest w Weronie i stąd też jego inna nazwa pochodzi od nazwy tego miasta: sacramentarium veronense.

Sakramentarz gelazjański zawiera tradycję liturgiczna przypisywana papieżowi Gelazemu (492-496). Jednak w tym sakramentarzu tylko część prefacji i modlitw jest autorstwa tego papieża. Natomiast wlaściwym twórcą tego kodeksu jest duchowny rzymski pochodzacy z VII w. Zbiór ten zawiera pelen zestaw modlitw używanych w czasie sprawowania liturgii w Rzymie w ciagu calego roku liturgicznego, jednak nie w liturgii papieskiej lecz w liturgii, której przewodniczyli miejscowi prezbiterzy.

Sakramentarz gregoriański jest przypisywany papieżowi Grzegorzowi Wielkiemu (590-604) i zawiera modlitwy liturgii papieskiej. Kodeks ten stanowi pelen zbiór modlitw na wszystkie obchody liturgiczne w ciagu calego roku kościelnego.

$$
{ }^{8} \mathrm{C} \text { a b i e, dz. cyt., s. 60-61. }
$$




\section{Pierwsze opisy liturgii mszalnej - Ordines Romani}

Razem z najstarszymi sakramentarzami pojawiaja się jeszcze inne zbiory tekstów dotyczacych liturgii, które nazywano Ordines Romani. Dziela te byly przeznaczone dla kręgu odbiorców, którzy nie znali zwyczajów liturgii rzymskiej.

W kodeksach tych umieszczano nie tylko zestawy modlitw danego obchodu liturgicznego, ale także szczególowy opis czynności liturgicznych, które należało wykonać. Zawieraly one również zwięzly wykład, dotyczący znaczenia poszczególnych obrzędów i sprawowanych w nich tajemnic Pańskich. Dziela te byly pierwszymi swego rodzaju przewodnikami drobiazgowo opisującymi liturgię rzymska, zawieraly pierwsze przepisy i zwyczaje liturgiczne.

\section{Inne księgi liturgiczne starożytności chrześcijańskiej - ewangeliarze, lekcjonarze, księgi śpiewów}

Jak wspomniano, wraz $z$ powstaniem Kościola mamy do czynienia $z$ niedziela czyli z nowym, cotygodniowym, specyficznie chrześcijańskim świętem. Każda niedziela byla dniem obchodu paschy Chrystusa. Istota tego świętowania było zgromadzenie wszystkich członków danej gminy (wspólnoty) i sprawowanie Eucharystii. Jednak, oprócz tej regularnej, cotygodniowej paschy, chrześcijanie zaczęli także bardzo wcześnie i uroczyście obchodzić kolejną rocznicę męki i śmierci Pana. Obchody te $\mathrm{z}$ oczywistych względów byly związane $\mathrm{z}$ terminem obchodu przez Żydów świąt paschalnych. Świętowanie to nazywano roczna paschq. W I i II w. przeżywanie tej „rocznicy” odbywało się według dwóch tradycji: jedna ściśle wiązala ten obchód ze świętami żydowskimi czyli z 14-stym dniem żydowskiego miesiąca nisan, druga zaś przenosila go na najbliższą niedzielę.

Tak więc najstarsze wspólnoty chrześcijańskie znaly obchód paschy „tygodniowej” i szczególnie uroczysty obchód paschy „rocznej”. Ten rytm dał początek obchodom poszczególnych tajemnic wiary (szczególnie zbawczych wydarzeń z ziemskiego życia Jezusa Chrystusa) w cyklu rocznym i przyczynił się do powstania „roku liturgicznego" z jego okresami i szczególowymi obchodami liturgicznymi.

Ta sytuacja sprawila, że w czasie Mszy świętych, sprawowanych w danym dniu liturgicznym, zaczęto odczytywać odpowiednio dobrane fragmenty Pisma św., aby one pelniej i jaśniej ukazywaly dane zbawcze wydarzenia i związane $z$ nimi tajemnice wiary. Oprócz tego na ksztalt zmian liturgii Słowa wplynęla również przejęta przez Kościól forma odczytywania tekstów biblijnych podczas nabożeństw w synagogach. Tam odczytywano fragmenty z Pięcioksięgu (Prawa), z ksiag prorockich (Proroków) i ksiagg dydaktycznych (Pism). Lekturę tę lączono ze śpiewem psalmów, homilią i modlitwą zgromadzenia. We wspólnotach chrze- 
ścijańskich momentem kulminacyjnym liturgii Slowa Bożego byla lektura Ewangelii, którą poprzedzaly dwa lub trzy Czytania ${ }^{9}$.

Upowszechniająca się praktyka odczytywania odpowiednio dobranych tekstów Pisma św. w czasie obchodów danej niedzieli czy święta, przyczyniła się do powstania zestawów czytań biblijnych. Takie „zestawy”, np. perykop ewangelicznych daly poczatek Księdze nazywanej Ewangeliarzem. Podobne zbiory obejmowaly pozostale czytania i śpiewy, które nazywano odpowiednio Lekcjonarzami czy Psalterzami. Oprócz nich znane byly również zbiory śpiewów wykonywanych w czasie liturgii takich jak antyfony (Antyfonarze) czy hymny (Hymnarze).

Spośród tych ksiagg szczególną czcią byl otaczany Ewangeliarz. Księga ta najczęściej byla bogato przyozdobiona, sam tekst Ewangelii był pisany złotymi literami. Kodeks ten uroczyście wnoszono do kościoła w czasie procesji wejścia i składano na oltarzu. Inną formą czci tej Księgi było jej calowanie i okadzanie.

\section{Geneza i dzieje mszału}

\section{Wyciag $\mathrm{z}$ ksiąg liturgicznych dla jednej celebracji - Missalae plenarium}

Wspanialy rozwój liturgii, której ośrodkiem zawsze byla niedzielna Msza św., sprawil, że począwszy od IV w. dla odpowiedniego jej sprawowania potrzebnych było jednocześnie kilka ksiag: sakramentarz, ewangeliarz, lekcjonarz i księga śpiewów. Księgi te powstawaly w skryptoriach zakonnych lub katedralnych, wymagaly wielu godzin pracy i najczęściej były prawdziwymi dziełami sztuki. Sporządzenie takich ksiag było bardzo kosztowne.

Na przełomie pierwszego i drugiego tysiąclecia chrześcijaństwa upowszechnil się nowy rodzaj księgi liturgicznej, którą nazwano Missalae plenarium (pelnym mszałem). Najstarszą znaną tego typu księga jest Mszal z Bobbio powstaly już w VIII w. Księga ta, w jednym tomie, zawierała wszystkie teksty potrzebne do odprawienia danej Mszy św. czyli: odpowiednie śpiewy, czytania i modlitwy. Byla więc zestawieniem formuł liturgicznych znajdujących się dotychczas w kilku księgach, przeznaczonych dla poszczególnych uczestników liturgii: celebransa, diakona, lektora, grupy śpiewaków. W Pelnym mszale teksty te zestawiono w jednym miejscu zgodnie z Ordo Missae czyli Porzadkiem sprawowania Mszy świętej.

\footnotetext{
${ }^{9}$ Por. C a b i e, dz. cyt., s. $75-85$
} 
Ten nowy typ księgi stanie się bardzo przydatny szczególnie wtedy, gdy Mszę św. sprawuje celebrans i niewielka grupa wiernych (czasami reprezentuje ją tylko jeden ministrant). Taka praktyka pojawi się na przełomie VIII i IX w. i będzie nosić nazwę tzw. Mszy prywatnych. Rozkwit tej praktyki przypada na XI i XII w., kiedy to wielu kaplanów codziennie bẹdzie sprawowało po kilka lub nawet kilkanaście Mszy św., z zasady bez udziału ludu. Wlaśnie to spowodowało szczególne „zapotrzebowanie” na taką księge liturgiczna, która by w jednym kodeksie zawierala niezbędne teksty dla sprawowania Mszy św. Zatem ten proces przyśpieszyl popularność pelnego mszału ${ }^{10}$.

Od tego czasu w ówczesnych skryptoriach będa powstawać przede wszystkim tego typu księgi liturgiczne. Podobnie było również i w znanym skryptorium metropolitalnym w Gnieźnie, gdzie powstaly i są przechowywane do dnia dzisiejszego następujące mszaly:

a) opatrzony sygnatura: Ms 149, powstal na przelomie XI i XII w.; zawiera Porzq̨dek sprawowania Mszy świętej (Ordo Romanus) i formularze mszalne calego Roku liturgicznego (Missale antiquissimum);

b) opatrzony sygnatura: Ms 147, powstal na przelomie XIII i XIV w.; zawiera Missale i kalendarz;

c) opatrzony sygnatura: Ms 93, powstal na przelomie XIV i XV w., w podtytule nosi nazwę: Mszal Gnieźnieński;

d) opatrzony sygnatura: Ms 141, powstal na przelomie XIV i XV w., w podtytule także nosi nazwę: Mszal Gnieźnieński.

\section{Mszal Trydencki}

Sobór Trydencki (1545-1563) zostal zwolany po wybuchu Reformacji przez papieża Pawla III. W ciagu XXV uroczystych sesji soborowych zajmował się sprawami wiary i reformą życia kościelnego ${ }^{11}$. Za pontyfikatu Juliusza III (15511552; sesje od X do XIV) zdefiniowal naukę Kościola o Eucharystii. Podkreślono w niej transsubstancjację chleba i wina we Mszy św., jej ofiarniczy charakter i realna obecność Chrystusa w Najświętszym Sakramencie ${ }^{12}$. Sobór zostal zamknięty za czasów Piusa IV, a nie dokończone sprawy jak wydanie mszalu, brewiarza i katechizmu, zostaly przekazane do załatwienia papieżowi.

Zobowiązanie to okazalo się jedną $\mathrm{z}$ największych zashug Tridentinum w dziedzinie liturgii. W czasie pontyfikatu papieża Piusa V wydano Mszal Rzymski (1570). Celem nowego mszalu było ujednolicenie sposobu sprawowania Mszy

\footnotetext{
${ }^{10}$ Por. C a b i e, dz. cyt., s. 154-155.

${ }^{11}$ M. B a n a s z a k: Historia Kościola Katolickiego. T. 3. Czasy nowożytne 1517-1758. Warszawa 1989 s. 98.

${ }^{12}$ Tamże, s. 100
} 
świętej w calym Kościele. Cel ten chciano osiagnać poprzez zamieszczenie w posoborowym mszale szczególowych rubryk. Zostaly one opracowane przez ceremoniarza papieskiego Jana Burcharda zgodnie z ,pierwotną normą świętych Ojców" (wierność tradycji) i treściami teologicznymi, jakie zawieral pierwszy posoborowy dokument papieski Katechizm rzymski (1566). Zaś nad poprawnościa wykonywania obowiązujących przepisów liturgicznych (rubryk) miala czuwać ustanowiona w 1588 r. Kongregacja Rytów.

Owocem reformy Soboru Trydenckiego byla także promulgacja pozostalych ksiąg liturgicznych, szczególnie brewiarza, rytualu i pontyfikalu. Na szczególną uwage zasluguje to, że po raz pierwszy w życiu Kościoła zostal ujednolicony mszal, który oprócz formul modlitewnych zawiera bardzo szczególowe rozporządzenia dotyczące sprawowania liturgii. Drugą nowością było powolanie przez papieża specjalnej instytucji odpowiedzialnej za dyscyplinę liturgiczną w Kościele powszechnym.

\section{Mszal Paryski (1738)}

Mszał Trydencki służył Kościołowi dokładnie czterysta lat. Wydano go już po siedmiu latach od zakończenia soboru. Ostatnie jego wydanie mialo miejsce w Rzymie w 1962 r.. Ten Mszal Piusa V, przyjęty także we Francji, zostal tam w XVII i XVIII w. ubogacony nowymi modlitwami i antyfonami. Na uwagę zastuguje fakt, że autorzy tych nowych tekstów czerpali inspirację dla ich powstania z ksiag biblijnych i z modlitw zawartych w starożytnych sakramentarzach. Tę „francuską" akomodację Mszału Trydenckiego określa się w historii liturgii jako Mszal Paryski (Missalae Parisiensis).

\section{Sobór Watykański II (1962-1965). Zasady odnowy obrzędów Mszy świętej}

Pierwszym dokumentem Soboru Watykańskiego II byla Konstytucja o Liturgii świętej Sacrosanctum Concilium. Zawierała ona postulat dotyczący także reformy obrzędów Mszy św. Celem tych zmian mialo być jaśniejsze ukazanie znaczenia poszczególnych części Eucharystii i ich wzajemnego związku, aby przez to wiernym ulatwić pobożny i czynny udzial w niej (por. nr 50). Aby to zamierzenie osiagnąć należy uprościć obrzędy, jednak zachowując wiernie ich istotę; opuścić to, co z biegiem czasu stalo się powtórzeniem lub dodatkiem bez większych korzyści. W procesie odnowy należy również przywrócić pewne elementy, zatracone w ciqgu wieków (...) stosownie do pierwotnej tradycji Ojców Kościola (por. tamże). 
Po tych ogólnych sformulowaniach Konstytucja domagała się następujących zmian szczególowych:

1) należy szerzej otworzyć skarbiec biblijny i wiernym obficiej zastawić stól słowa Bożego (por. nr 51);

2) w czasie samej liturgii należy glosić homilię (por. nr 52); nr 53)

3) Po Ewangelii i homilii należy przywrócić modlitwę powszechnq (por.

4) w celu lepszego rozumienia tekstów można pozwolić w odpowiednim zakresie, we mszach odprawianych $z$ udzialem wiernych, na stosowanie języka ojczystego (por. 54);

5) po Komunii kaplana wiernym należy udzielać Ciała Pańskiego z tej samej Ofiary; zaś w wypadkach, które określi Stolica Apostolska wierni będą mieli możliwość otrzymania Komunii św. pod dwiema postaciami;

6) Sobór zobowiązal także duszpasterzy, aby gorliwie uczyli wiernych o obowiązku uczestniczenia w calej Mszy św. (por. 56);

7) ostatnim postulatem Soboru bylo przywrócenie praktyki koncelebry.

\section{Posoborowy Mszał Pawla VI}

\section{Wydanie posoborowego mszalu (1970)}

Realizacja powyższych postulatów soborowych dotyczacych odnowienia sprawowania Eucharystii znalazla swoje potwierdzenie w wydaniu posoborowego mszalu. Zostal on ogloszony przez Pawla VI i wydany przez Kongregację dla Spraw Kultu Bożego w Wielki Czwartek, 26 marca 1970 r. Wzorcowe wydanie mszalu obejmuje 1000 stron o formacie $8^{*}(17 \mathrm{X} 24 \mathrm{~cm})$ i ozdobione jest 14 drzeworytami G. Luigi Uboldi z Mediolanu.

We wstępnej części mszalu zostaly opublikowane następujące dokumenty: Dekret Kongregacji do Spraw Kultu Bożego, Konstytucja Apostolska Pawla VI Missale Romanum, Ogólny wstęp do Mszalu Rzymskiego (OWMR), Motu Proprio Pawla VI Mysterii paschalis oraz Ogólne Normy Roku liturgicznego i Kalendarza. Mszal zamyka Dodatek, w którym umieszczono: obrzęd pokropienia woda święconą, wzory modlitwy powszechnej, obrzęd blogoslawieństwa nadzwyczajnego szafarza Komunii św., przygotowanie celebransa do Mszy św. i dziękczynienie po niej oraz melodie śpiewów mszalnych.

Mszal tworzą następujące części: Msze roku liturgicznego, obrzędy Mszy św., Msze wlasne o świętych, Msze wspólne, Msze obrzędowe, Msze i modlitwy w różnych potrzebach. Msze wotywne i Msze za zmarlych. Na końcu umieszczono indeksy imion i prefacji oraz spis treści. 


\section{Cechy posoborowego mszalu z r. 1970}

Mszal Pawla VI stanowi przede wszystkim kontynuację Mszalu Piusa V, z którego przejęto znakomita większość tekstów. Nowe formuly stanowią tylko okolo $10 \%$. Redaktorzy nowego mszalu, podobnie jak redaktorzy Mszalu Trydenckiego pragnęli, by mszal wyrażal pierwotna regułę modlitwy (pristinam orandi regulam), a same zaś odnowione obrzędy Mszy św. byly zgodne z normami Świętych Ojców (sanctorum patrum normam).

Sobór Watykański II posiadal charakter pastoralny. Pragnąl przystosować formy gloszenia orędzia zbawienia (aggiornamento) do czasów sobie wspólczesnych. Chciał wyrazić bogactwo wiary Kościola objawiajace się w jego modlitwie liturgicznej (lex credendi statuat lex orandi) w lepszej harmonii z językiem dzisiejszej myśli teologicznej i wspólczesnego życia Kościola oraz wspólczesnej mentalności czlowieka.

Zatem Mszał Pawla VI częściej niż Mszał Trydencki stosuje teksty biblijne w formulach liturgicznych: wersetach, oracjach, prefacjach itp. Częściej także umieszcza teksty patrystyczne. Formuly mszalne lącza słowa Pisma św. z wypowiedziami Ojców, a także $z$ doktrynalnymi wypowiedziami Kościoła, szczególnie $\mathrm{z}$ tekstami soborowymi, tworząc jedną liturgiczną całość.

W tekstach nowego mszalu znajdujemy również szczególny akcent polożony na wyrażenie centralnej tajemnicy objawienia, jaka jest misterium paschalne Jezusa Chrystusa oraz ukazanie obecności i dzialania Ducha Świętego.

Z nową formą celebrowania Eucharystii ściśle się wiążą dokumenty dotyczace odnowy kalendarza liturgicznego, ustalajacego porządek i hierarchię poszczególnych uroczystości, niedziel i innych obchodów liturgicznych, a także dokumenty dotyczace porządku czytań.

Największą nowością Vaticanum II jest ubogacenie mszalnej liturgii Słowa i przyjęcie w Kościele zachodnim tradycji celebrowania Eucharystii w oparciu o różne Modlitwy eucharystyczne. Dotychczasowa praktyka Kościola rzymskiego, jaką było poslugiwanie się tylko jedną anafora - Kanonem Rzymskim, zostala po Soborze ubogacona przez przyjęcie nowych Modlitw eucharystycznych. W posoborowym Mszale w części Obrzędy Mszy świętej oprócz Kanonu Rzymskiego (określonego również jako I Modlitwa eucharystyczna) znajdujemy także trzy inne Modlitwy eucharystyczne. Ubogacenie zaś liturgii Slowa zaowocowalo powstaniem Lekcjonarza Mszału Rzymskiego, którego lacińskie wydanie miało miejsce 30 września 1970 r. w święto św. Hieronima. 


\section{Drugie wydanie Mszalu Pawla VI (1975)}

W 1975 r. ukazalo się drugie wydanie wzorcowe posoborowego mszahu. Uwzględnialo ono zmiany jakie nastapily $\mathrm{w}$ prawodawstwie liturgicznym po 1970 r. (szczególnie związane z reformą święceń i nowe obchody liturgiczne). $\mathrm{Na}$ podstawie tej wersji mszału przygotowano polską edycję mszału (1986 r.).

\section{Mszal wydany z okazji Wielkiego Jubileuszu Dwutysiąclecia Chrześcijaństwa (2002)}

\section{Przyczyny trzeciego wydania posoborowego mszału (2002)}

Wśród przyczyn trzeciego wydania nowego mszalu wymienia się następujace:

1. uwzględnienie zmian zawartych $w$ księgach liturgicznych wydanych po roku 1975 ;

2. wprowadzenie w Kalendarzu Rzymskim (Powszechnym) w latach 19762002_nowych obchodów ku czci Świętych;

3. Doprecyzowanie i wyjaśnienie norm już istniejących, dotyczących sprawowania Mszy św.

\section{Nowe elementy w trzeciej edycji posoborowego mszalu}

1. Dodano nowe teksty liturgiczne:

a) w części Mszy wspólnych o Najświętszej Maryi Pannie dołączono formularz o Bożej Rodzicielce,

b) w części Msze wlasne o Świętych dodano szereg formularzy mszalnych dotyczących nowych obchodow umieszczonych w Kalendarzu Powszechnym,

c) Umieszczono nowe modlitwy we formularzach Mszy Wspólnych, w Mszach i modlitwach w różnych potrzebach, a także w Mszach za Zmarlych.

2. W części mszału zatytulowanej Obrzędy Mszy świętej umieszczono tylko I, II, III i IV Modlitwę eucharystyczna. Wszystkie zaś pozostałe Modlitwy eucharystyczne (I i II Modlitwę eucharystyczną o Tajemnicy Pojednania oraz inne Modlitwy eucharystyczne „w różnych potrzebach”) umieszczono w Dodatku.

3. We wszystkich formularzach Mszy Wielkiego Postu, zgodnie ze starożytnym zwyczajem liturgicznym, przywrócono dawną modlitwę nad ludem jako specjalna formulę blogostawienstwa .

4. W Ogólnym Wprowadzeniu tego mszału dodano zupełnie nowy rozdzial IX, zatytułowany Adaptacje zależne od kompetencji biskupów oraz Konferencji Episkopatu. W tym rozdziale wymieniono szczególowe uprawnienia biskupów w 
zakresie adaptacji obrzędów liturgicznych do miejscowych warunków i przedstawiono ściśle określony sposób wprowadzania ich w życie (por. $\mathrm{nr} 390)^{13}$.

Glównym celem trzeciego wydania wzorcowego posoborowego mszału było gorące pragnienie zachowania i wyrażenia nieskażonej tradycji wiary Kościoła od czasów apostolskich dotyczącej Eucharystii. Formuly zawarte w nowym mszale i szczególowe normy dotyczace celebracji wskazuja na troskę Kościola, jego wiarę i niezmienioną miłość wobec Mszy św.

Niewypowiedziany Dar Mszy św. Kościól otrzymal od Pana Jezusa podczas Ostatniej Wieczerzy za pośrednictwem Apostolów. Poprzez ten Dar, Chrystus na cale wieki aż do swego przyjścia, utrwalit ofiare Krzyża i powierzył ją Kościolowi, aby nieustannie sprawowal pamiątke Jego Męki i Zmartwychwstania i przyjmowal zaproszenie Chrystusa do udzialu w Jego zbawczej Ofierze.

Nawet pobieżne zaznajomienie się z wybranymi zagadnieniami sprawowania Mszy św. w dziejach Kościola wskazuja, że byla ona zawsze w centrum Jego życia. Chrześcijanie zaś mieli żywą świadomość, że stają wobec zdumiewajacego daru Chrystusa i niepojętej tajemnicy, z której - jak ze źródła - wyplywa woda żywa. Ten dar domagal się właściwego przyjęcia: wysilku intelektualnego i duchowego, ale przede wszystkim wiary, będacej owocem pokornego otwarcia się na laskę. Przez wieki, dla kolejnych pokoleń chrześcijan, czymś oczywistym byl - chociaż różnie rozumiany - regularny udział w niedzielnej Mszy św.

Trwala zaś obecność Chrystusa Zmartwychwstalego pod Postaciami Chleba i Wina domagala się i rodzila różnorodne formy adoracji. Udzial we Mszy św. i adoracja Chrystusa Eucharystycznego przynosily duchowe przeżycia i stawaly się zobowiązaniem do rozwoju wlasnego życia duchowego we wspólnocie Kościoła oraz do budowania nowej cywilizacji sprawiedliwości, wolności, pokoju i milości.

\footnotetext{
${ }^{13}$ M. B a r b a: La Genesi Istituzionale dell ',Editio typica Tertia” del „Missale Romanum”. „Notitiae”. R. 38: 2002 s. 56-62.
} 
